\title{
GH signaling in human adipose and muscle tissue during 'feast and famine': amplification of exercise stimulation following fasting compared to glucose administration
}

\author{
Mikkel H Vendelbo ${ }^{1,2}$, Britt Christensen ${ }^{1,3}$, Solbritt B Grønbæk ${ }^{1}$, Morten Høgild ${ }^{3}$, \\ Michael Madsen ${ }^{1,2}$, Steen B Pedersen ${ }^{1}$, Jens $O$ L Jørgensen ${ }^{1}$, Niels Jessen ${ }^{1,3}$ \\ and Niels Møller ${ }^{1}$ \\ Departments of ${ }^{1}$ Endocrinology and Internal Medicine, ${ }^{2}$ Nuclear Medicine and PET Center and \\ ${ }^{3}$ Research Laboratory for Biochemical Pathology, Aarhus University Hospital, Nørrebrogade 44 \\ 8000 Aarhus, Denmark
}

\author{
Correspondence \\ should be addressed \\ to $\mathrm{M} \mathrm{H}$ Vendelbo \\ Email \\ Mikkel.Vendelbo@ki.au.dk
}

\begin{abstract}
Objective: Fasting and exercise stimulates, whereas glucose suppresses $\mathrm{GH}$ secretion, but it is uncertain how these conditions impact GH signaling in peripheral tissues. To test the original 'feast and famine hypothesis' by Rabinowitz and Zierler, according to which the metabolic effects of $\mathrm{GH}$ are predominant during fasting, we specifically hypothesized that fasting and exercise act in synergy to increase STAT-5b target gene expression.

Design and methods: Eight healthy men were studied on two occasions in relation to a $1 \mathrm{~h}$ exercise bout: i) with a concomitant i.v. glucose infusion ('feast') and ii) after a $36 \mathrm{~h}$ fast ('famine'). Muscle and fat biopsy specimens were obtained before, immediately after, and $30 \mathrm{~min}$ after exercise.

Results: GH increased during exercise on both examination days and this effect was amplified by fasting, and free fatty acid (FFA) levels increased after fasting. STAT-5b phosphorylation increased similarly following exercise on both occasions. In adipose tissue, suppressors of cytokine signaling 1 (SOCS1) and SOCS2 were increased after exercise on the fasting day and both fasting and exercise increased cytokine inducible SH2-containing protein (CISH). In muscle, SOCS2 and CISH mRNA were persistently increased after fasting. Muscle SOCS1, SOCS3, and CISH mRNA expression increased, whereas SOCS2 decreased after exercise on both examination days.

Conclusions: This study demonstrates that fasting and exercise act in tandem to amplify STAT-5b target gene expression (SOCS and CISH) in adipose and muscle tissue in accordance with the 'feast and famine hypothesis'; the adipose tissue signaling responses, which hitherto have not been scrutinized, may play a particular role in promoting FFA mobilization.
\end{abstract}

European Journal of Endocrinology

(2015) 173, 283-290

\section{Introduction}

Growth hormone $(\mathrm{GH})$ and its principal intracellular signal mediator, STAT-5b, represent a well-preserved endocrine control system, which throughout evolution has served to maintain growth and lean body mass and to regulate intermediary metabolism (1). In adipocytes and skeletal muscle, STAT-5b serves as a transcription factor for target genes including a family of
(C) 2015 European Society of Endocrinology Printed in Great Britain cytokine-inducible suppressors of cytokine signaling (SOCS) (1, 2, 3), cytokine inducible SH2-containing protein (CISH) $(2,4)$, and insulin-like growth factor 1 (IGF1). GH has important actions to regulate anabolic signals and preserve lean body mass protein (1); some of these anabolic effects are mediated by stimulation of lipolysis $(5,6)$. 
In a classic paper Rabinowitz \& Zierler (7) introduced the concept of a 'feast and famine cycle', according to which insulin is the major anabolic hormone storing fuels during periods of food surplus ('feast') and which GH initiated activation of fat depots and high levels of free fatty acids (FFAs) safeguard the individual during stress and famine by restricting protein loss.

Since then a number of studies have lent support to the role of GH in the feast and famine concept. Studies in humans have shown that during fasting GH substantially (>30\%) reduces protein breakdown and this effect depends on mobilization of FFA from lipid stores $(5,6)$. In the basal state (after an overnight fast), it has been difficult to document consistently the anabolic effects of GH (1).

In addition it has been reported that $\mathrm{GH}$ increases phosphorylation of STAT-5b in human muscle and fat (8) and activates SOCS1-3, CISH, and IGF1 mRNA expression in skeletal muscle $(4,9,10)$. Stress conditions such as exercise and fasting with increased $\mathrm{GH}$ secretion have also been shown to stimulate human skeletal muscle STAT-5b phosphorylation and IGF1 mRNA expression $(11,12)$, although it is unclear whether this involves stimulation of SOCS/CISH transcription. In adipose tissue it remains uncertain how fasting and exercise affect human STAT-5b signal transduction.

To further explore the viability of the feast and famine concept, we conducted the present study to test whether spontaneous and exercise-stimulated GH secretion and subsequent intracellular activation of STAT-5b phosphorylation and target gene expression in muscle and fat are amplified during famine conditions as opposed to feast. We used a $36 \mathrm{~h}$ fast to reproduce 'famine' and a continuous infusion of glucose to mimic 'feast'.

\section{Methods}

\section{Ethical approval}

All participants gave written, informed consent in accordance with the Declaration of Helsinki II. The local ethics scientific committee approved the study.

\section{Subjects}

Eight healthy men (age $27 \pm 5$ years, body weight $77.9 \pm 6 \mathrm{~kg}$, BMI $24.7 \pm 2 \mathrm{~kg} / \mathrm{m}^{2}$, and $\mathrm{VO}_{2 \text {-peak }} 4034 \pm$ $588 \mathrm{ml} / \mathrm{min}$ ) participated.

\section{Protocol}

On both experimental days, the subjects completed a $1 \mathrm{~h}$ cycling exercise at $50 \% \mathrm{VO}_{2 \text {-peak }}$ or until fatigued, after a
60 min baseline period. Prior to one of the experimental days the subjects fasted for $36 \mathrm{~h}$. On the other experimental day, the subjects received a continuous glucose infusion after a $12 \mathrm{~h}$ overnight fast: $0.2 \mathrm{~g} / \mathrm{kg}$ per $\mathrm{h}$ for $1 \mathrm{~h}$ (baseline period), $1 \mathrm{~g} / \mathrm{kg}$ per $\mathrm{h}$ during the $1 \mathrm{~h}$ of exercise, and $0.2 \mathrm{~g} / \mathrm{kg}$ per $\mathrm{h}$ for the remaining $2 \mathrm{~h}$ (post exercise). Baseline skeletal muscle biopsies and blood samples were obtained $1 \mathrm{~h}$ before exercise $(t=-60)$, immediately after exercise $(t=60)$, and $30 \mathrm{~min}$ into the recovery period $(t=90)$. Biopsies were sampled alternately from the right and left M. vastus lateralis using a Bergström needle and immediately frozen in liquid nitrogen. Adipose tissue biopsies were sampled from the abdominal subcutaneous adipose tissue $1 \mathrm{~h}$ before exercise initiation $(t=-60)$ and $30 \mathrm{~min}$ into the recovery period $(t=90)$ using a lipid suction technique and then immediately washed free of blood and frozen in liquid nitrogen (Fig. 1).

\section{Blood analysis}

Plasma glucose was immediately measured (Beckman Instruments, Brea, CA, USA). Serum samples were stored at $-20{ }^{\circ} \mathrm{C}$, and $\mathrm{GH}$ and insulin were analyzed using immunoassays (AutoDELFIA; PerkinElmer, Turku, Finland), as was C-peptide (DakoCytomation, Cambridgeshire, UK). FFA was analyzed by a commercial kit (Wako Chemicals, Neuss, Germany).

\section{Western blotting}

The frozen skeletal muscle and adipose tissue samples were crushed into powder in a frozen steel mortar. The tissue powder was homogenized in an ice-cold lysis buffer (adipose tissue: $20 \mathrm{mM}$ HEPES, $10 \mathrm{mM} \mathrm{NaF}, 1 \mathrm{mM}$ $\mathrm{Na}_{3} \mathrm{VO}_{4}, 1 \mathrm{mM}$ EDTA, 5\% SDS, $50 \mu \mathrm{g} / \mathrm{ml}$ soybean trypsin inhibitor, $4 \mu \mathrm{g} / \mathrm{ml}$ leupeptin, $0.1 \mathrm{mM}$ benzamidine, $2 \mu \mathrm{g} / \mathrm{ml}$ antipain, $1 \mu \mathrm{g} / \mathrm{ml}$ pepstatin; skeletal muscle: $20 \mathrm{mM}$ Tris- $\mathrm{HCl}, 50 \mathrm{mM} \mathrm{NaCl}, 250 \mathrm{mM}$ sucrose, $50 \mathrm{mM}$ $\mathrm{NaF}, 5 \mathrm{mM} \mathrm{Na}_{4} \mathrm{P}_{2} \mathrm{O}_{7}, 1 \%$ Triton X-100, $5 \mu \mathrm{g} / \mathrm{ml}$ leupeptin, $1.5 \mu \mathrm{g} / \mathrm{ml}$ benzamidine, $500 \mu \mathrm{M}$ phenylmethylsulphonyl fluoride, $50 \mu \mathrm{g} / \mathrm{ml}$ soybean trypsin inhibitor, and $2 \mathrm{mM}$ dithiothreitol) using a Precellys homogenizer (Bertin Technologies, Montigny-le-Bretonneux, France). Insoluble materials were removed by centrifugation at $14000 \boldsymbol{g}$ for $20 \mathrm{~min}$ at $4{ }^{\circ} \mathrm{C}$. The lipid-free infranatant was isolated three times in adipose tissue before being used for western blotting. In the skeletal muscle, protein concentration of the supernatant was determined using a Bradford assay (Bio-Rad). Samples were adjusted to equal concentrations with Milli-Q Water and denatured by mixing with 


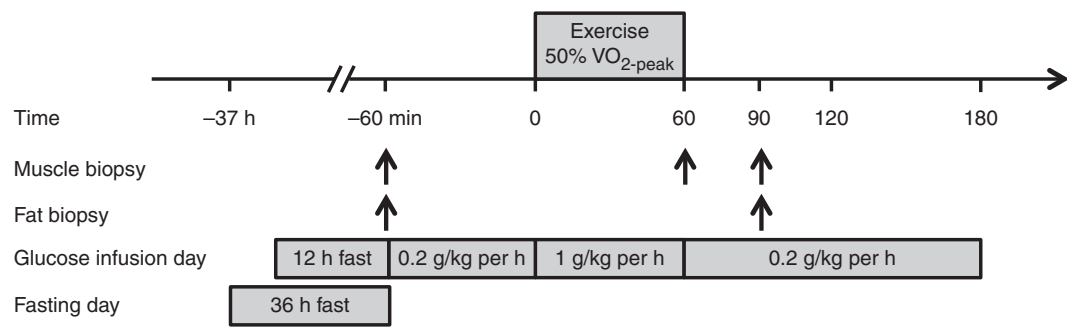

\section{Figure 1}

Schematic presentation of the study design. On two experimental days, the subjects completed a $1 \mathrm{~h}$ cycling exercise bout at $50 \% \mathrm{VO}_{2 \text {-peak. }}$ One bout (glucose infusion day) was performed with continuous glucose infusion $(0.2 \mathrm{~g} / \mathrm{kg}$ per $\mathrm{h}$ for $1 \mathrm{~h}$ (baseline period), $1 \mathrm{~g} / \mathrm{kg}$ per $\mathrm{h}$ during the $1 \mathrm{~h}$ of exercise, and $0.2 \mathrm{~g} / \mathrm{kg}$ per $\mathrm{h}$ for the remaining $2 \mathrm{~h}$ (post exercise)) after a $12 \mathrm{~h}$ overnight fast, and the other bout (fasting day) was performed

Laemmli's buffer and heating at $95^{\circ} \mathrm{C}$ for $5 \mathrm{~min}$. Equal amounts of protein were separated by SDS-PAGE using the Bio-Rad Criterion system, and proteins were electroblotted onto PVDF membranes (Bio-Rad) as described $(13,14)$. Control for equal loading was assessed with Stain-Free technology. Membranes were blocked for $2 \mathrm{~h}$ in a 2\% BSA solution (Sigma-Aldrich) and incubated overnight with primary antibodies against phosphorylated STAT-5b Tyr $^{699}$ and STAT-5b (Cell Signaling Technology, Beverly, MA, USA).

\section{Real-time PCR}

Frozen skeletal muscle and adipose tissue powder ( $\sim 30 \mathrm{mg}$ ) were homogenized using TRIzol reagent added DNAse and Protein kinase K (Gibco BRL, Life Technologies), and total RNA was extracted following the manufacturer's protocol. RNA was quantified by measuring absorbance at 260 and $280 \mathrm{~nm}$ using a NanoDrop 8000 (NanoDrop Products, Bancroft, DE, USA), and inclusion criteria were a ratio $\geq 1.8$. Integrity of the RNA was checked by visual inspection of the two ribosomal RNAs, $18 \mathrm{~S}$ and 28S, on an agarose gel. cDNA was synthesized with the TaqMan Gold RT-PCR Kit (PerkinElmer, Boston, MA, USA). Real-time PCR for SOCS1-3, $\mathrm{CISH}$, and IGF1 were assessed with mRNA levels of $\beta$-actin as an internal control. The following primers were used: SOCS1: 5'-ACACGCACTTCCGCACATTC-3' and 5'-CGAGGCCATCTTCACGCTAAG-3'; SOCS2: 5'-GGTCGAGGCGATCAGTG-3' and 5'-TCCTTGAAGTCAGTGCGAATC-3'; SOCS3: 5'-GCCCTTTGCGCCCTTT-3' after $36 \mathrm{~h}$ of fasting. The order of the two experimental days was randomized and separated by $\sim 1$ month. Skeletal muscle biopsies and blood were sampled $60 \mathrm{~min}$ before exercise initiation, immediately after exercise termination, and $30 \mathrm{~min}$ into the recovery period. Furthermore, adipose tissue biopsies were performed $60 \mathrm{~min}$ before exercise and $30 \mathrm{~min}$ into the recovery period.

and 5'-CGGCCACCTGGACTCCTATGA-3'; CISH: 5'-GCCCTGAGCCCTGGTAGTCC-3' and 5'-GACACATTC ACAGACGGGTGG-3'; IGF1： 5'-GACAGGGGCTTTTA TTTCAAC- $3^{\prime}$ and $5^{\prime}$-CTCCAGCCTCCTTAGATCAC-3 ${ }^{\prime}$; and $\beta$-actin: 5'-ACGGGGTCACCCACACTGTGC- $3^{\prime}$ and 5'-CTAGAAGCATTTGCGGTGGACGATG-3'.

\section{Statistical analysis}

Results are expressed as means \pm s.E.M. Normal distribution was assessed by inspection of QQ plots, and the Levene median test was used to test for equal variance. The effects of experimental day and time/exercise interaction were assessed by one-way- and/or two-way repeated-measurements ANOVA, with Student-Newman-Keul's post hoc testing.

\section{Results}

\section{Circulating hormones and metabolites}

GH concentrations were unchanged after $36 \mathrm{~h}$ of fasting. Subjects performed $1 \mathrm{~h}$ ergometer cycling at $50 \%$ of $\mathrm{VO}_{2 \text {-peak, }}$ with average workloads of $139 \pm 6.4 \mathrm{~W}$ (glucose) and $135 \pm$ 6.5 Watt (W) (fasting) (Table 1). All participants completed $1 \mathrm{~h}$ of exercise on both experimental days, apart from one subject who fatigued after 45 min of exercise on the fasting day. Exercise increased circulating GH levels on both days, significantly more so after fasting. Fasting increased FFA levels, which rose further after exercise; during glucose infusion, FFA concentrations remained suppressed and levels of glucose, insulin, and C-peptide increased. 
Table 1 Effect of 36 hours fasting and one hour ergometer cycling at $50 \% \mathrm{VO}_{2}$-peak on growth hormone (GH), glucose, insulin, C-peptide, and free fatty acid (FFA) concentrations in serum. Throughout the table pre-exercise is indicated with $t=-60$, immediately after exercise is indicated with $t=60$, and $30 \mathrm{~min}$ after exercise is indicated with $t=90$ on both examination days. Furthermore, fasting experimental day is illustrated with Fasting day and glucose infusion day is illustrated with Glucose day.

\begin{tabular}{|c|c|c|c|c|c|c|}
\hline & \multicolumn{3}{|c|}{ Glucose day } & \multicolumn{3}{|c|}{ Fasting day } \\
\hline & $t=-60$ & $t=60$ & $t=90$ & $t=-60$ & $t=60$ & $t=90$ \\
\hline $\mathrm{GH}(\mathrm{ng} / \mathrm{ml})$ & $1.13 \pm 0.4$ & $3.52 \pm 1.0 *$ & $1.10 \pm 0.3$ & $1.33 \pm 0.6$ & $6.05 \pm 1.3 * t$ & $2.29 \pm 0.6$ \\
\hline Glucose (mM) & $5.26 \pm 0.1$ & $7.78 \pm 0.8 *$ & $5.35 \pm 0.4$ & $4.37 \pm 0.2^{\dagger}$ & $4.64 \pm 0.4^{\dagger}$ & $4.30 \pm 0.3^{\dagger}$ \\
\hline Insulin (pM) & $29.74 \pm 3.7$ & $137.35 \pm 22.0$ * & $64.11 \pm 19.4^{*}$ & $20.87 \pm 3.8$ & $34.74 \pm 9.5^{\dagger}$ & $20.66 \pm 4.9^{\dagger}$ \\
\hline C-peptide (pM) & $543.75 \pm 33$ & $1475.63 \pm 16 *$ & $1073.63 \pm 17 *$ & $341.63 \pm 61$ & $405.50 \pm 69^{\dagger}$ & $364.38 \pm 66^{\dagger}$ \\
\hline FFA (mM) & $0.36 \pm 0.07$ & $0.18 \pm 0.04$ & $0.12 \pm 0.02$ & $0.90 \pm 0.11^{\dagger}$ & $1.70 \pm 0.15^{*}+$ & $1.10 \pm 0.14^{\dagger}$ \\
\hline
\end{tabular}

${ }^{*} P<0.05$ vs $t=-60$ within experimental day and ${ }^{\dagger} P<0.05$ vs same time point on glucose infusion experimental day.

\section{GH signaling in adipose tissue and skeletal muscle}

Phosphorylation of STAT-5b $\mathrm{Tyr}^{699}$ was unaltered in adipose and skeletal muscle after $36 \mathrm{~h}$ of fasting compared to the overnight fast (Figs $2 \mathrm{~A}$ and $3 \mathrm{~A}$ ). Exercise dramatically increased STAT-5b Tyr ${ }^{699}$ phosphorylation in fat and muscle without significant differences between examination days. A trend $(P=0.074)$ toward increased phosphorylation was observed immediately after exercise $(t=60)$ in skeletal muscle on the fasting examination day compared to the glucose infusion day.

\section{STAT-5b target genes in adipose tissue}

In adipose tissue, a significant main effect of the experimental day was observed on mRNA expression of SOCS1-2 and CISH, while only a trend $(P=0.061)$ was observed in regard to SOCS3 (Fig. 2B, C, D, E and F). Post hoc testing revealed that SOCS1-2 and CISH mRNA expressions were significantly elevated $30 \mathrm{~min}$ after exercise $(t=90)$ on the fasting day compared to glucose infusion. Exercise induced detectable $(P<0.05)$ increments in SOCS1-2 and CISH mRNA after $36 \mathrm{~h}$ of fasting, whereas only CISH expression increased after exercise combined with glucose infusion. IGF1 mRNA expressions remained unaltered.

\section{STAT-5b target genes in skeletal muscle}

In skeletal muscle, a significant main effect of the experimental day was observed on mRNA expression of SOCS2 and CISH, and post hoc testing revealed that expression levels on each biopsy time point were significantly increased on the fasting experimental day compared to the glucose infusion day (Fig. 3B, C, D, E and F). A main effect of time/exercise was observed on SOCS1-3 and CISH mRNA expression. SOCS1, SOCS3, and CISH mRNA expressions were increased immediately after exercise $(t=60)$ on both experimental days, sOCS3 expression being significantly higher on the glucose infusion day at $t=60$. On both examination days, SOCS3 and CISH mRNA expression was significantly increased $30 \mathrm{~min}$ after exercise termination $(t=90)$. Post hoc testing revealed that SOCS2 mRNA expressions were equally suppressed on both time points ( $t=60$ and 90) after exercise on the glucose infusion day, whereas this effect did not reach statistical significance on the fasting examination day. Again, IGF1 mRNA expressions remained unaltered.

\section{Discussion}

This study was designed to test whether exercise-stimulated GH signaling in fat and muscle is amplified after fasting compared to a glucose infusion. Our data show that exercise strongly stimulates STAT-5b phosphorylation and that SOCS1-2 and CISH expression in fat, and SOCS2 and CISH expression in muscle increase after fasting and remain increased in response to exercise. These findings support the 'feast and famine' concept by locating a stronger intracellular GH signal in two major metabolic target tissues as a mechanism, whereby $\mathrm{GH}$ exerts distinct metabolic effects during conditions of stress, such as fasting and exercise.

In the present study we opted for i.v. administration of nutrients to imitate fed conditions, because this allows controlled steady state conditions, which are not dependent on unpredictable gastrointestinal absorption. We chose glucose alone as an energetically simple compound, which is typically used as a supplement during prolonged exercise and excludes amino acids and lipids, which may 

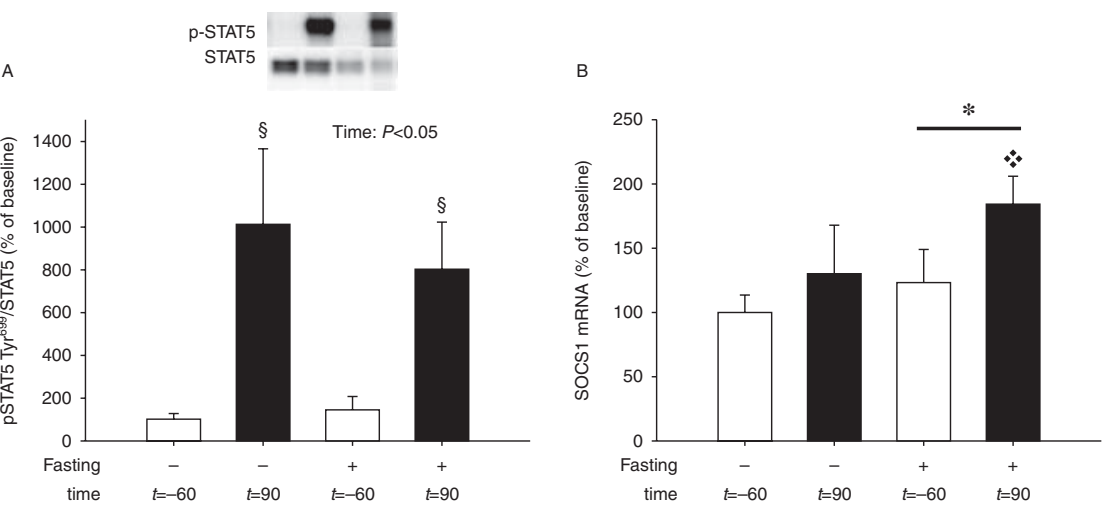

$\mathrm{E}$

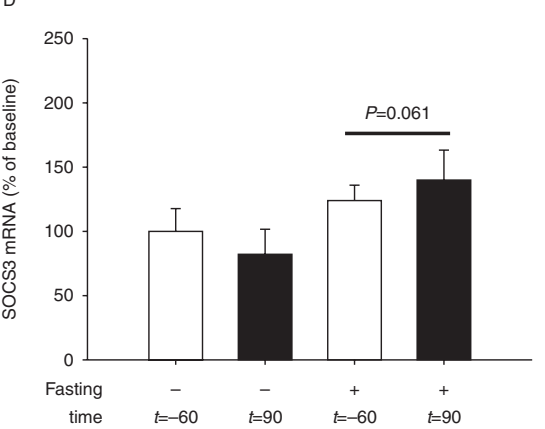

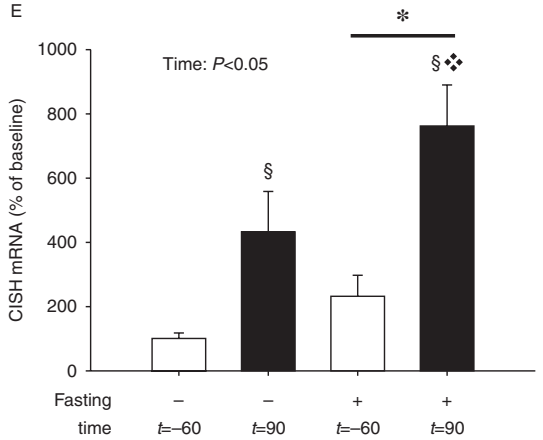

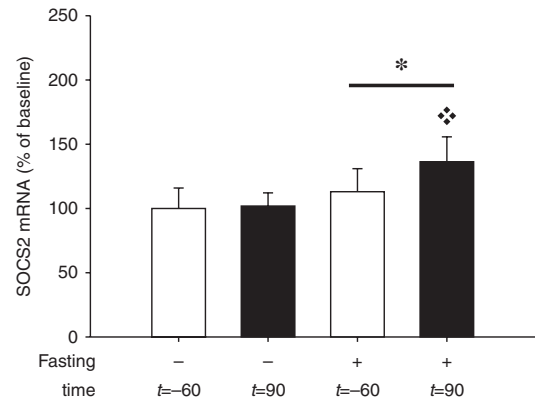

$\mathrm{F}$

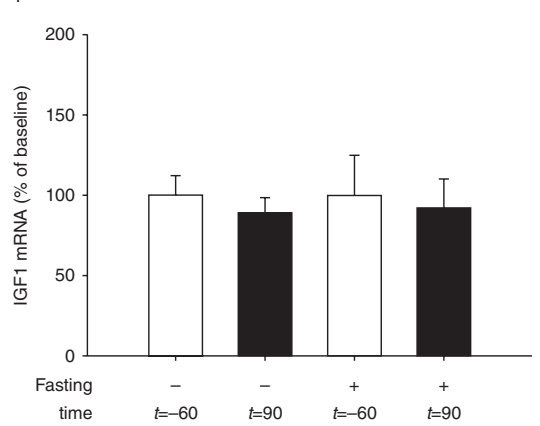

Figure 2

Effects of $36 \mathrm{~h}$ of fasting and $1 \mathrm{~h}$ of ergometer cycling at $50 \% \mathrm{VO}_{2 \text {-peak }}$ on growth hormone signaling in adipose tissue were assessed with western blotting and real-time PCR. White bars indicate pre-exercise $(t=-60)$ and black bars indicate 30 min after exercise $(t=90)$ on both examination days. + , Fasting experimental day; - , glucose infusion day; *, main effect of experimental day $=P<0.05$; time $=P<0.05$, main effect of time/exercise; ${ }^{\S} P<0.05$ vs $t=-60$ within the experimental day; ${ }^{\star} P<0.05$ vs same time point on glucose infusion day. (A) STAT-5b $\mathrm{Tyr}^{699}$ phosphorylation was unaltered after $36 \mathrm{~h}$ of fasting but increased after exercise $(t=90)$ on both examination days. (B and C) mRNA expression of SOCS1 and SOCS2 was significantly increased after $36 \mathrm{~h}$ of fasting. However, post hoc testing revealed that SOCS1 and SOCS2 mRNA expression were only increased after exercise on the fasting experimental day compared to the glucose infusion day. (D) There was a trend $(P=0.061)$ toward increased SOCS3 mRNA expression levels after $36 \mathrm{~h}$ of fasting. (E) mRNA expression of $\mathrm{CISH}$ was significantly increased after $36 \mathrm{~h}$ of fasting, and post hoc testing revealed that it was increased on both time points ( $t=-60$ and 90$)$ on the fasting experimental day compared to the glucose infusion day. Furthermore, CISH mRNA expression increased after exercise $(t=90)$ in adipose tissue on both examination days compared to pre-exercise levels within the experimental day. $(F)$ No changes were observed on IGF1 mRNA expression after fasting or exercise.

affect GH secretion independently (1). We did not detect increased baseline levels of GH after $36 \mathrm{~h}$ of fasting, which could relate to the relatively short period of fasting and the 'elusive' pulsatile nature of GH secretion. Previous studies with more frequent blood sampling have shown increased $\mathrm{GH}$ concentrations after $72 \mathrm{~h}$ of fasting (12), and GH levels during exercise were increased after fasting in the present study. It is therefore likely that the increased intracellular $\mathrm{GH}$ signal following exercise on the fasting examination day to a large extent is a direct consequence of increased circulating levels of GH. On the other hand, high levels of FFA as observed during fasting have been shown to dampen muscle STAT-5b phosphorylation by up to $40 \%$, which may counterbalance stimulation of the intracellular signal (15). The present study design does not allow discrimination between the contribution of increased GH concentrations and altered intracellular signaling cascade sensitivity and responsiveness to $\mathrm{GH}$. The impact of fasting on the doseresponse effects of $\mathrm{GH}$ on signal transduction and metabolism are not well characterized. One study has shown increased lipolytic responsiveness in the presence of decreased STAT-5b phosphorylation after a GH bolus during fasting in healthy volunteers (16), compatible with increased distal signal transduction in adipocytes. In this 
A

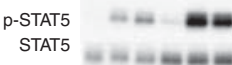

STATS $=\pi=\pi=0 \quad$ Time: $P<0.05$
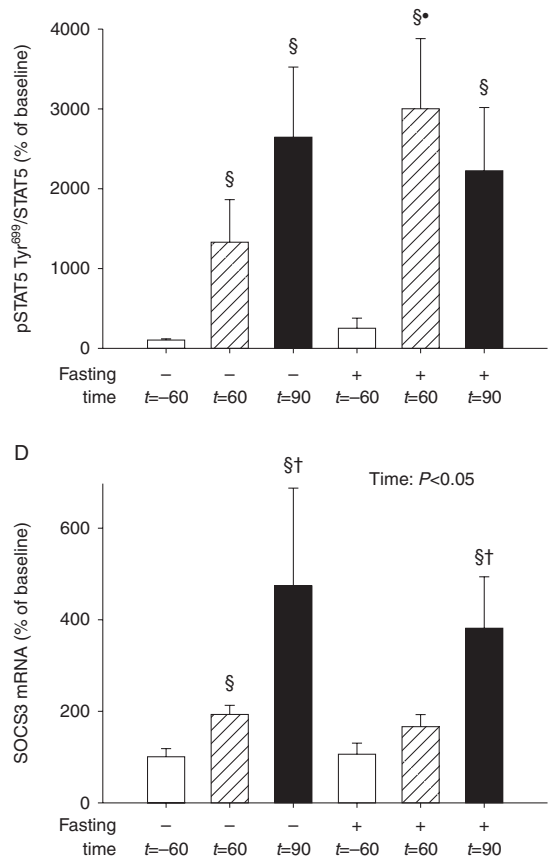

B

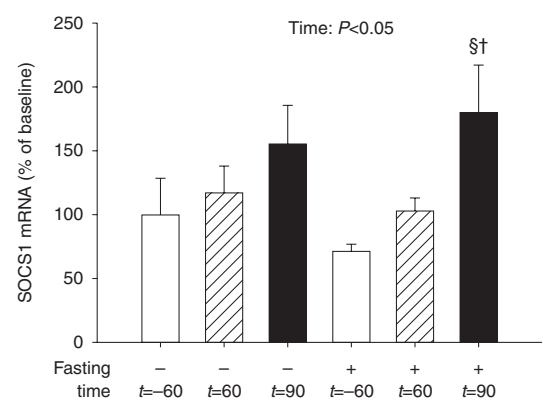

E

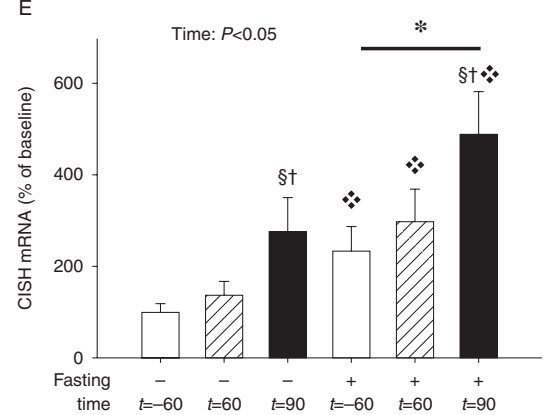

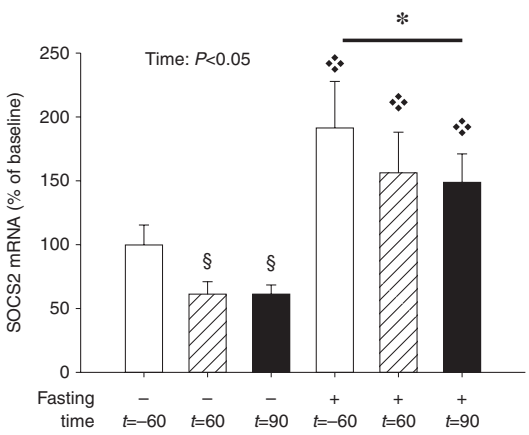

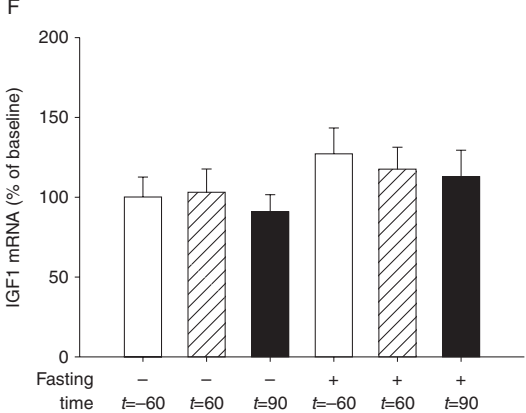

Figure 3

Effect of $36 \mathrm{~h}$ of fasting and $1 \mathrm{~h}$ of ergometer cycling at $50 \% \mathrm{VO}_{2 \text {-peak }}$ on growth hormone signaling in skeletal muscle tissue were assessed with western blotting and real-time PCR. White bars indicate pre-exercise $(t=-60)$, dashed bars indicate immediately after exercise $(t=60)$, and black bars indicate $30 \mathrm{~min}$ after exercise $(t=90)$ on both examination days. + , Fasting experimental day; - , glucose infusion day; ${ }^{*}$, main effect of experimental day $=P<0.05 ;{ }^{\S} P<0.05$ vs $t=-60$ within the experimental day; ${ }^{\dagger} P<0.05$ vs $t=60$ within experimental day; ${ }^{\star} P<0.05$ vs same time point on glucose infusion day; and $\bullet P=0.074$ vs same time point on glucose infusion day. (A) STAT-5b Tyr ${ }^{699}$ phosphorylation was unaltered after $36 \mathrm{~h}$ of fasting but increased on both time points after exercise $(t=60$ and 90) on both examination days. Furthermore, there was a trend toward higher STAT-5b phosphorylation immediately after exercise $(t=60)$ on the fasting experimental day compared to the glucose infusion day. (B) SOCS1 mRNA expression was unaltered after $36 \mathrm{~h}$ of fasting, but there was a main effect of time/exercise $P<0.05$, and post hoc testing revealed that expression was significantly increased $30 \mathrm{~min}$ after exercise $(t=90)$ on the fasting experimental day. (C) mRNA expression of SOCS2 was significantly increased after $36 \mathrm{~h}$ of fasting. Post hoc testing revealed that SOCS2 mRNA expression was increased on all time points after fasting compared to the glucose infusion day. Furthermore, there was a main effect of time/exercise $P<0.05$, and post hoc testing revealed that SOCS2 mRNA expression was significantly decreased immediately after $(t=60)$ and 30 min after exercise $(t=90)$ on the glucose infusion day. (D) SOCS3 mRNA expression was unaltered after $36 \mathrm{~h}$ of fasting, but there was a main effect of time/exercise $P<0.05$, and post hoc testing revealed that expression was significantly increased immediately after exercise $(t=60)$ and 30 min after exercise $(t=90)$ on the glucose infusion day and $30 \mathrm{~min}$ after exercise $(t=90)$ on the fasting experimental day. (E) There was a main effect of fasting on CISH mRNA expression, and post hoc testing revealed that expression was increased on all time points after fasting compared to the glucose infusion day. Furthermore, there was a main effect of time/exercise $P<0.05$, and post hoc testing revealed that CISH mRNA expression was significantly increased $30 \mathrm{~min}$ after exercise $(t=90)$ on both examination days. (F) No significant changes were observed on IGF1 mRNA expression after fasting or exercise.

context it should be underlined that many other factors, including insulin, cortisol, epinephrine, FFA, ketone bodies, and the autonomous nervous system, may modulate the lipolytic response to $\mathrm{GH}$.
Several human in vivo studies have shown that during fasting the protein conserving actions of GH progressively increase (5), that these effects involve inhibition of muscle protein breakdown (5), and that protection of protein 
depends critically on increased levels of FFA (6), thereby highlighting the central role of GH-stimulated lipolysis in adipose tissue. In addition, a study in GH-deficient subjects with or without $\mathrm{GH}$ administration reported that the most significant metabolic action of GH during exercise is the stimulation of lipolysis (17). The precise cascade of events whereby GH stimulates adipose tissue lipolysis is incompletely understood, and there is a lack of human in vivo studies examining these events. Administration of GH to normal subjects increases STAT-5b phosphorylation and SOCS3 mRNA in adipose tissue (10) and a recent study in JAK2 knockout mice reported impaired lipolysis (18).

The biological function of the SOCS/CISH proteins is mainly to feedback inhibit the JAK/STAT signaling pathway (1). The increments in individual SOCS/CISH proteins may thus be seen as a part of a feedback loop controlling $\mathrm{GH}$ effects and the ensuing stimulation of lipolysis. Interestingly, SOCS3 overexpression in mouse adipose tissue has been shown to cause local insulin resistance (19) and deletion of skeletal muscle SOCS3 prevents insulin resistance in obese mice (20).

In this study we did not observe significant effects of $36 \mathrm{~h}$ of fasting on STAT-5b phosphorylation or IGF1 mRNA levels. We have previously observed that more prolonged fasting tends to increase both STAT-5b phosphorylation and IGF1 mRNA levels in muscle (12), implying that intracellular GH signaling is further augmented during longer periods of fasting.

Fasting and exercise are catabolic states during which the energy balance of the body is negative and, as such, a threat to survival. In 1963 Rabinowitz \& Zierler (7) introduced their 'feast and famine' cycle and proposed that $\mathrm{GH}$ acted as a key conservator of protein during catabolic stress. The present data add novel features to this concept by showing that exercise-induced stimulation of GH signaling activity in vivo is amplified by fasting at the level of SOCS and CISH target gene expression in skeletal muscle and adipose tissue in human subjects.

\section{Declaration of interest}

The authors declare that there is no conflict of interest that could be perceived as prejudicing the impartiality of the research reported.

\section{Funding}

This work was supported by the FOOD Study Group/Danish Ministry of Food, Agriculture, and Fisheries, and the Ministry of Family and Consumer Affairs Grant 2101-05-0044 (to N Møller).

\section{Acknowledgements}

Hanne Petersen and Elsebeth Hornemann are thanked for skilled technica assistance during the studies.

\section{References}

1 Moller N \& Jorgensen JO. Effects of growth hormone on glucose, lipid, and protein metabolism in human subjects. Endocrine Reviews 200930 152-177. (doi:10.1210/er.2008-0027)

2 Fleenor D, Arumugam R \& Freemark M. Growth hormone and prolactin receptors in adipogenesis: STAT-5 activation, suppressors of cytokine signaling, and regulation of insulin-like growth factor I. Hormone Research 200666 101-110. (doi:10.1159/000093667)

3 Galic S, Sachithanandan N, Kay TW \& Steinberg GR. Suppressor of cytokine signalling (SOCS) proteins as guardians of inflammatory responses critical for regulating insulin sensitivity. Biochemical Journal 2014461 177-188. (doi:10.1042/BJ20140143)

4 Clasen BF, Krusenstjerna-Hafstrom T, Vendelbo MH, Thorsen K, Escande C, Moller N, Pedersen SB, Jorgensen JO \& Jessen N. Gene expression in skeletal muscle after an acute intravenous GH bolus in human subjects: identification of a mechanism regulating ANGPTL4. Journal of Lipid Research 201354 1988-1997. (doi:10.1194/jlr.P034520)

5 Norrelund H, Nair KS, Jorgensen JO, Christiansen JS \& Moller N. The protein-retaining effects of growth hormone during fasting involve inhibition of muscle-protein breakdown. Diabetes 200150 96-104. (doi:10.2337/diabetes.50.1.96)

6 Norrelund H, Nair KS, Nielsen S, Frystyk J, Ivarsen P, Jorgensen JO, Christiansen JS \& Moller N. The decisive role of free fatty acids for protein conservation during fasting in humans with and without growth hormone. Journal of Clinical Endocrinology and Metabolism 2003 88 4371-4378. (doi:10.1210/jc.2003-030267)

7 Rabinowitz D \& Zierler KL. A metabolic regulating device based on the actions of human growth hormone and of insulin, singly and together, on the human forearm. Nature 1963199 913-915. (doi:10.1038/ 199913a0)

8 Jorgensen JO, Jessen N, Pedersen SB, Vestergaard E, Gormsen L, Lund SA $\&$ Billestrup N. GH receptor signaling in skeletal muscle and adipose tissue in human subjects following exposure to an intravenous $\mathrm{GH}$ bolus. American Journal of Physiology. Endocrinology and Metabolism 2006 291 E899-E905. (doi:10.1152/ajpendo.00024.2006)

9 Krusenstjerna-Hafstrom T, Madsen M, Vendelbo MH, Pedersen SB, Christiansen JS, Moller N, Jessen N \& Jorgensen JO. Insulin and GH signaling in human skeletal muscle in vivo following exogenous $\mathrm{GH}$ exposure: impact of an oral glucose load. PLoS ONE 20116 e19392. (doi:10.1371/journal.pone.0019392)

10 Nielsen C, Gormsen LC, Jessen N, Pedersen SB, Moller N, Lund S \& Jorgensen JO. Growth hormone signaling in vivo in human muscle and adipose tissue: impact of insulin, substrate background, and growth hormone receptor blockade. Journal of Clinical Endocrinology and Metabolism 200893 2842-2850. (doi:10.1210/jc.2007-2414)

11 Consitt LA, Wideman L, Hickey MS \& Morrison RF. Phosphorylation of the JAK2-STAT5 pathway in response to acute aerobic exercise. Medicine and Science in Sports and Exercise 200840 1031-1038. (doi:10.1249/MSS. Ob013e3181690760)

12 Vendelbo MH, Jorgensen JO, Pedersen SB, Gormsen LC, Lund S, Schmitz O, Jessen N \& Moller N. Exercise and fasting activate growth hormonedependent myocellular signal transducer and activator of transcription-5b phosphorylation and insulin-like growth factor-I messenger ribonucleic acid expression in humans. Journal of Clinical Endocrinology and Metabolism 201095 E64-E68. (doi:10.1210/jc.2010-0689)

13 Vendelbo MH, Clasen BF, Treebak JT, Moller L, KrusenstjernaHafstrom T, Madsen M, Nielsen TS, Stodkilde-Jorgensen H, Pedersen SB, Jorgensen $\mathrm{JO}$ et al. Insulin resistance after a 72-h fast is associated with 
impaired AS160 phosphorylation and accumulation of lipid and glycogen in human skeletal muscle. American Journal of Physiology. Endocrinology and Metabolism 2012302 E190-E200. (doi:10.1152/ ajpendo.00207.2011)

14 Nielsen TS, Vendelbo MH, Jessen N, Pedersen SB, Jorgensen JO, Lund S \& Moller N. Fasting, but not exercise, increases adipose triglyceride lipase (ATGL) protein and reduces $\mathrm{G}(0) / \mathrm{G}(1)$ switch gene 2 (GOS2) protein and mRNA content in human adipose tissue. Journal of Clinical Endocrinology and Metabolism 201196 E1293-E1297. (doi:10.1210/jc.2011-0149)

15 Moller N, Gormsen LC, Schmitz O, Lund S, Jorgensen JO \& Jessen N. Free fatty acids inhibit growth hormone/signal transducer and activator of transcription-5 signaling in human muscle: a potential feedback mechanism. Journal of Clinical Endocrinology and Metabolism 200994 2204-2207. (doi:10.1210/jc.2008-2624)

16 Moller L, Dalman L, Norrelund H, Billestrup N, Frystyk J, Moller N \& Jorgensen JO. Impact of fasting on growth hormone signaling and action in muscle and fat. Journal of Clinical Endocrinology and Metabolism 200994 965-972. (doi:10.1210/jc.2008-1385)
17 Kanaley JA, Dall R, Moller N, Nielsen SC, Christiansen JS, Jensen MD \& Jorgensen JO. Acute exposure to GH during exercise stimulates the turnover of free fatty acids in GH-deficient men. Journal of Applied Physiology 200496 747-753. (doi:10.1152/japplphysiol. 00711.2003)

18 Shi SY, Luk CT, Brunt JJ, Sivasubramaniyam T, Lu SY, Schroer SA \& Woo M. Adipocyte-specific deficiency of Janus kinase (JAK) 2 in mice impairs lipolysis and increases body weight, and leads to insulin resistance with ageing. Diabetologia 201457 1016-1026. (doi:10.1007/ s00125-014-3185-0)

19 Shi H, Cave B, Inouye K, Bjorbaek C \& Flier JS. Overexpression of suppressor of cytokine signaling 3 in adipose tissue causes local but not systemic insulin resistance. Diabetes 200655 699-707. (doi:10.2337/ diabetes.55.03.06.db05-0841)

20 Jorgensen SB, O'Neill HM, Sylow L, Honeyman J, Hewitt KA, Palanivel R, Fullerton MD, Oberg L, Balendran A, Galic S et al. Deletion of skeletal muscle SOCS3 prevents insulin resistance in obesity. Diabetes 201362 56-64. (doi:10.2337/db12-0443)

Received 29 December 2014

Revised version received 24 May 2015

Accepted 1 June 2015 